Respiration 2010;80:262

DOI: $\underline{10.1159 / 000315474}$

\section{Isolated Recurrent Pleuritis Revealing Familial Mediterranean Fever in Adulthood}

\section{J.C. Lega, C. Khouatra, V. Cottin, J.F. Cordier}

Reference Center for Rare Pulmonary Diseases,

Department of Respiratory Medicine, Louis Pradel Hospital, Claude Bernard University (Lyon I), Lyon, France

We thank Dr. Cantarini et al. for their comments concerning our case report. We agree with these authors that the recognition of FMF and TRAPS as aetiologies of recurrent pleural effusion is a significant progress in this field. However, it should be noted that recurrent pleural effusions are still a clinical dilemma for chest physicians and internists. Indeed, contrary to recurrent pericardial effusions $[1,2]$, this area is marked by the paucity of published data. Beyond research in autoinflammatory diseases, we advocate multicentric cohort studies to describe the aetiologies, natural history, clinical manifestations, prognosis and treatment of recurrent pleural effusion, and to help physicians resolve this medical challenge.

\section{References}

1 Maisch B, Seferović PM, Ristić AD, Erbel R, Rienmüller R, Adler Y, et al, Task Force on the Diagnosis and Management of Pericardial Diseases of the European Society of Cardiology: Guidelines on the diagnosis and management of pericardial diseases executive summary. Eur Heart J 2004;25:587-610.

-2 Adler Y, Finkelstein Y, Guindo J, Rodriguez de la Serna A, Shoenfeld Y, Bayes-Genis A, et al: Colchicine treatment for recurrent pericarditis: a decade of experience. Circulation 1998;97:2183-2185.

J.F. Cordier, MD

Department of Respiratory Medicine, Louis Pradel Hospital

28 avenue Doyen Lépine

FR-69677 Bron Cedex (France)

Tel. +33 472357 269, Fax +33 472357653

E-Mail jean-françois.cordier@chu-lyon.fr

\section{KARGER}

Fax +41 613061234 E-Mail karger@karger.ch www.karger.com
(C) 2010 S. Karger AG, Basel

0025-7931/10/0803-0262\$26.00/0 